Historic, Archive Document

Do not assume content reflects current scientific knowledge, policies, or practices. 



\section{Spring Price List of}

Higher Types of Small Fruits and Flowers

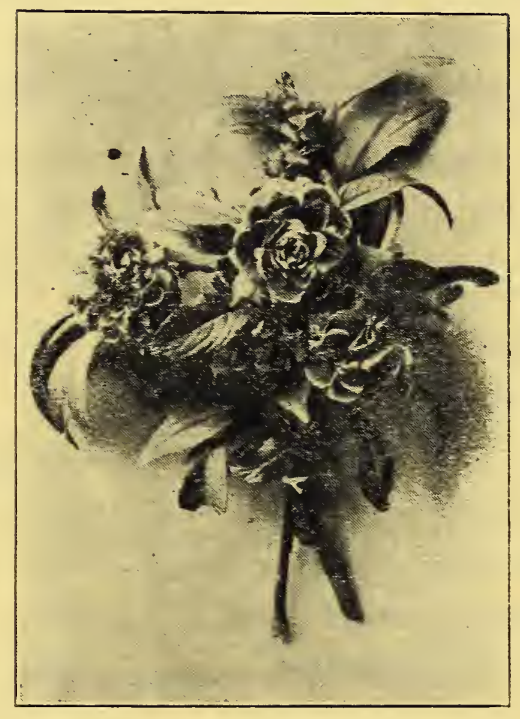

Balsam Superflora

Grown and For Sale by

JOHN L. WILSON

Elk City, Kansas 
To My Patrons And Friends.

Most sincerely I thank you for your fatrors in the past, and trust I may have the pleasure cf suppying this year a liberal share of your needs in the items listed herewith.

Last seasnn was very favorable for plants to grow, and most of my stock is exceptionally fine, especially strawberries, blackberries, flower seeds and bull:s. The State Nursery Inspectors were with me three times last summer, once to inspect my stock, and twice exploring the mysteries of insect life in this vici ity. We also enjoyed the little visits of many who came to see the flowers. You are always welcome when the flowers are in bloom.

Everything listed in this catalogue will be delivered prepaid by mail or express unless otherwise noted. Everything is guaranteed to be true to name as labeled and to reach you in good condition, or the purchase price will be refunded or stck replace-t, but I will not guarantee stock to grow, nor the crop, as I have no controll over conditions under which it is planted. Nor under no condition will I be responsible for a greater amount than the purchase price.

Yours very truly,

John L. Wilson. 
John L. Wilson-Higher Types of Small Fruits and Flowers-Elk City, Kan.

\section{DAHLIAS}

Plant Dahlias in any good garden soil in rows three feet apart, eighteen inches apart in the row, about six inches deep, after danger of frost is past. Lay the tubers down flat with bud looking up, instead of standing them on end. Cultivate thoroughly always, deeply at first, but after the blooms appear, keep only the surface worked so as not to disturb the roots. Pinching the tops of the plants when there are four leaves on them w:ll induce them to branch at the ground, sending up four main stalks instead of one, and increase the number of flowers, but retard their blooming about two weeks. Whens the buds aypear, pinching out the smaller buds as soon as formed, will throw more strength into those that remain, producing larger flowers.

Sometimes a plant forms so many little buds and branches that none can develop into flowers. Then you should pinch out a lot of buds and branches, giving what remain a chance to develop.

After they are killed by frost in the fall dig the whole clump together very carefully so as not to break off the tubers. Cut the stalk off, l:aving about an inch of it to the clumy. Let it dry in the sun a little, (two or thre? hours) and place upsida down in a cocl frost-proof cellar until Syring. When dividing the clumps, cut off a part of the old stalk in each division, being careful not to break the tubers off at the neck. The buds do no: grow on the body of the tubers, but on the crown or bulsing poition where it connects to tha old stalk.

\section{DECORATIVE DAHLIAS}

Darlene. An early flowering, free blooming variety, large flowers of delicate shell-pink, blending to white at centers. Each 35c.

Dr. Thurman (New). Large flowers with petals of clear yellow with a blend of copper tints fine and a free blomer. Each 30c.

Elsie Davidson. Large deep golden yellow. Each 25 c.

Jack Rose. Deep crimson, very popular and a good one. Each 25c; Doz. \$2.50.

Mina Burgle. Deep glowing crimson, blooms profusely from early till frost. Large flowers on long stems. One of the very best crimson Dahlias. Each 30c; Doz. \$3.00.

Oregon Beauty. This is a very large, ball-shaped dahlia of beautiful glowing scarlet. Exceptionally free fowering. Long wiry stems make it unsurpassed for cutting. Each 35c; Doz. $\$ 3.50$.

Souv. de Gustar Doazon. Beautiful orange-red of gigantic size. This is the largest flowering dahlia in the world. Full to the center and often measuring eight or nine inches across. and can be forced to twelve inches in diameter. Plant is tall and vigorous, long stiff stems, one of the best. Each $30 \mathrm{c} ;$ Doz. $\$ 3.00$.

\section{SHOW AND FANCY DAHLIAS}

This class are the round, ball-shaped dahlias, most of which have the outer petals turned back and almos: touching the stem. 
Maude Adams, one of the best, in a mixture at a very low price. And white overlaid with delicate pink. in buying this mixture whether by Each 40 c.

Miss Helen Hollis, bright cherry red. Each 35c.

Tillamook, fine lavender pink. Each $35 \mathrm{c}$.

Winite Swan, pure white, very free flowering. Each 25c.

\section{POMPON DAHLIAS}

These are little fellows, not more than two inches across and full double. They bloom fuller than the large flowering types and do not require disbudding.

Amber Queen, amber color, Each 25c; Doz. \$2.50.

Catherine, bright yellow. Each 35c.

Midget, salmon, edged pink. Each $35 c$.

Pink Pom. Note: This is not truly a pompon because it is a little too large. It may have a name but I do not know what it is, and it has been so highly admired by many visitors I use the name only for convenience in listing it. A lovely shade of pink and very profuse bloomer. Each 25c.

\section{MIXED SEEDLING DAHLIAS}

Last summer I was very well pleased with a field of a few hundred varieties of seedling dahlias grown from my own seed. I have reserved the very best of these for my own planting to be introduced later under names. The worst and all single ones were thrown away. I offer the rest the dozen or fifty, I assure you no two will be alike. Some kinds are similar but no tivo exactly the sama variety. The colors are pure white, several shades of yellow, lavender, pink, red and purple, also the autumn shades. Each 15c; Doz. \$1.50; per $100, \$ 11.00$.

Mixed Dahlia Seed. These are from all varieties I grew that made seed last summer. I think my gardens contained about every color known to dahlias. No two of these seeds will be likely to produce the same kinds of flowers. Most of them should ba double, and of good size. You never can tell what they will produce, but a few might be exceptionally fine. From a package of this seed you might get a dahlia that is finer than any yet produced. Nobody can tell. Plant them about one half inch dee? in good soil after danger of frost is over, cultivate well and most of them should bloom this fall.

Fer package of a few seed, 25c. Note: My supply of this dahlia seed is limited. Early orders will be filled, and should I be sold out before I get your order, the money will be returned.

\section{GLADIOLI}

This is one of the finest flowers for cutting, is easily grown, requires little space, but should have a sunny position. While some new varieties sell at enormous prices those I list are yet among the best and are low in price. Plant them from four to six inches deep, from four to six inches ainart in the row. 
Spikes cut when the first bloom opens will continue to bloom in water until all the buds have opened as well as out in the garden.

America, pink. Each 5c; Doz. 50c.

Arlon, light salmon, one of the best of its color. Each 5c; Doz. 50c.

Barron J. Hulot, dark violet blue. A little small but the only one of its color. Each 15c; Doz. \$1.50.

Crimson Glow, deep scarlet red. Fine large flowers on tall spike. Each $10 \mathrm{c} ;$ Doz. $\$ 1.00$.

Elora, white with pink markings, large and fine. Each 5c; Doz. 50c.

Flora, yellow, large and one of the best yellows. Each 10c; Doz. \$1.00.

Gen. Joffre, a fine deep scarlet with darker markings. Each 10c; Doz. $\$ 1.00$.

Le Marechal Foch, one of the finest and best of light pink color. Each 10c; Doz. $\$ 1.00$.

Mrs. Francis King. F.ed with darker and lighter markings. Very large fine blooms. Each 10c; Doz. $\$ 1.00$

Myra, salmon and pink. Very large flowers. Each 10c; Doz. $\$ 1.00$.

Best Mixed. This mixture contains on!y fine varieties, in mostly large flowered type. Per Doz. 50c; 6 at $25 c$.

Hybrids Mixed. These are mostly primulinus hybrids, and colors are mostly yellow, salmon, pink and bronze. A large number planted together make a nice display and bloom for a long season. Note the low price: Per 12, 25c; per $100, \$ 2.00$.

\section{CANNAS}

I have only the President this year to offer but it is the very finest deep glowing largest scarlet flowers. Each 10 ; Doz. $\$ 1.00$.

\section{TUBEROSES}

Pure waxy white, very fragrant, Double, Each 5c; Doz. 50c; Single, Each 10c; Doz. \$1.00.

\section{PEONIES}

These are easily grown and when established will bloom for years without much care. They should be taken up and divided and moved to a new location every few years for best blooms. Planted this spring these 3 to 5 eye divisions I offer will not be likely to bloom this sunmmer but will get well established for blooming next year. Do not put manure in the hills when planting. Any fairly ric'l soil is good. Plant with eyes or buds about one inch only below the surface.

Edulus Superba, early bright pink, full center, double, fragrant and good grower. Each 60c.

Festiva Maxima, early to midseason. Very large double white flowers with carnine markings. Of hundreds of varieties of peonies, this is one of the very best white ones. Each 50c.

Felix Crousse, large ball shaped, rich red, one of the best of its color. Each $\$ 1.00$. 
John L. Wiison-Higher Types of Small Fruits and Flowers-Elk City, Kan.

Miadam Forel glossy pink with deeper rose center, double, very fragrant, and a choice pink variety. Each $\$ 1.00$

\section{HARDY PERENYIAL PLANTS}

The hardy perennials when once planted come up every spring and bloom for years without much trouble. I offer strong divisions of clumps or one or two year seedlings.

Aquilegia or Columbine, th:s is one of the best perennial flowe:s, and suitable for partial shade, many colors, mixed seedlings. Each 15c; 12 for $\$ 1.50$.

Dianthus Barbatus or Sweet William, various colored flowers in flat topped clusters, mixed seedlings. Each $15 \mathrm{c} ; 12$ for $\$ 1.50$.

Dianthus Plumarius or Hardy Garden Pink, carnation-like flowers in mixed shades of red, pink and white. mixed. Each 15c; 12 for $\$ 1.5$ ?

Gaillardia or B'anket Flowcr this is one of the best plants to bloom from early summer till freezing weather and withstands drouth and heat well. Red, orange and yel'ow shades. Each $15 \mathrm{c}$; Doz. $\$ 1.50$.

Lathyrus or Hardy Sweet Pea. climbing vine bears large clusters of flowers like sweet peas, but are not fragrant. Each 15c; 12 for $\$ 1.50$.

Liatris or Kansas Gay Feather, native perennial growing two to four feet tall with spike of purple flowers in late autumn. Plant bulblike root only one inch under ground.Each 20c.
Phlox, large heads of lovely sweet scented flowers in shades of red and pink and pure white. State color wanted. Each 25c; 5 for $\$ 1.00$.

Ludbeckia or Golden Glow, bright yellow flowers in autumn. Each $15 \mathrm{c}$.

Salvia Azurea or Native Blue Sage, bearing spikes of dark blue, grows two to four feet high. Each 15c; 12 for $\$ 1.50$.

Salvia Farnaceae, of compact growth two feet high and bears a mass of silvery blue spikes. Each 15:; 12 for $\$ 1.50$.

Siberian Iris, slender grass like blades and lovely dark blue flowers on spikes eighteen inches high. Each $20 \mathrm{c}$.

Lilly of the Valley, bears spikes of little fragrant waxy white bell shaped flowers. Each 5c; Doz. 50c.

Veronica or Speedwell, dark blue flowers six to twelve inches high. Each 10c; Doz. \$1.00.

Vio'a Odorata or Sweet English Violets. Each 10c; Doz. \$1.00.

\section{HARDY CLIMBING AND FLOWER- ING VINES}

Celastrus Scandens or American Bittersweet. Tall vines live all winter, bearing bright red seed pods in the fall. Each 30c.

Cinnamon Vine. Vines die down to ground each fall and sprout up from the root in spring. Small sweet scented white flowers. Each 10; Doz. \$1.

Dutchman's Pipe Vine. Tall growing vines live from year to year, leaf- 
ing out each spring, bearing pretty leaves and odd flowers. Each 20c.

Honeysuckle Scarlet Trumpet. Each $40 \mathrm{c}$.

Hop Common Native. Vines make quick growth each spring from roots and die down to the ground in fall. Each 20c; Doz. \$2.00.

Japanese Kudzu. Tall rapid grower dense foliage dies down in fall and comes up from roots in spring. Each $25 \mathrm{c}$.

Wisteria, purple, 1 yr. each 30c; 3 yr. each 50c.

Wisteria, white, 1 yr. each $30 \mathrm{c} ; 3$ yr. each 50c.

\section{FLOWER SEEDS}

I am not offering a long list of flower seeds, but these thirty-six varieties grow and bloom well in my own gardens. I list most of them only by the package, but if you want them in ounces or half ounces for larger planting, write for prices of the kinds and quantities you require. Also I will be pleased to obtain for your special need seed of any known flower you desire which I do not grow.

Antirrhinum or Snapdragon, dwarf nixed colors. pkt. 10c.

Balsum Superflora or Touch-menot. This is my own new balsam which has a different habit of growth than the common kinds. Each branch produces a very large full double rose like flower on the very top above all the leaves. This makes it when in full blcom one of the most gorgeous and showy plants in the garden, and the flowers are much more adapted for cutting than the older kinds whose flowers are more nearly hidden beneath the leaves. The only color I have to offer yet is a lovely shade of red. Pkt. 25c.

Balsam. Double flowered. This is the old common touch-me-not, but mine are only the fullest double flowers and in many beautiful shades of red, lavender, varigated and pure white. Mixed pkt. 10c.

Calendula, or Pot Marigold. This grows about one foot high for me and bears several shades of yellow flowers Pkt. 5c.

California Poppy. Somewhat fernlike blue green foliage, bearing single flowers in several shades of yellow and pink. Grows hardly one foot high. mixed pkt. 5c.

Chinese Woolflower. This bears large heads of bright red, somewhat resembling a ball or bunch of wool. It belongs to the same family the cockscombs do, pkt. 5c

Cockscomb. Tall crested red. This grows three or four feet tall and bears enormous heads of bright crimson. The side branches of these should be kept cut off to produce the largest head on the central stalk, pkt. 5c.

Cockscomb. Tall crested mixed colors. These have flowers of pink, rose, pellow and nearly white pkt. 5c.

Centaurea Cyanus or Cornflower, mixed pkt. 5c. 
John L. Wilson-Higher Types of Small Fruits and Flowers-Elk City, Kan.

Centaurea Americana, a large thistle like flower, lilac color. Pkt. 50c.

Centaurea Impearialis or Sweet Sultan, all colors mixed. Pkt. 10c.

Daisy, Oxeye, hardy perennial white. Pht. 10c.

Daturea large trumpet-shaped white flowers very sweet scented, blooming at evening. Pkt. 5c.

I iower of an Hour, larga flower's, cream color with purple centers, opening in midday, three to five feet tall. Pkt. 10s.

I'our C'Clock, sweet scented, blooming at evening. Pkt. ${ }^{5}$.

Gaillardia, hardy perennial. This is one of the best flowers to bloom continciously fiom early summer until frost, bearing large single and sami-double flowers of yellow with red cєnters in several shades. Excellent for cutting and stands drouth and heat betier than most flowers. Pkt. 10c.

Liatris or Kansas Gay Feather. Hardy perennial growing two to three fecé tall, bearing a spike of purple flowers in late autumn. Plit. 10c.

Larkspur. Annual, single flowered, in purple, blue lavender. pink and white. ..Mixed pkt. 10c.

Nasturtium, dwarf. Mixed Pkt. 5c; oz. 15c.

Petunia, single bedding. These are exceptionally pretty and free flowering in several shades of red and striped but no white ones. Pkt. 15c.
Petunia, Royal Purple Giants. These have large single flowers of richest purple. Pkt. 20c.

Phlox Drummondi Grandiflora. These bloom profusely all summer, and my mixture contains a very great variety of colors. They are simply gorgeous. All Colors, mixed. Pkt. 10c.

Poppy, Flanders Field. These are branching plants one foot high be:r. ing large numbers of single flowers, one and one half to two inches across of brightest glowing sca:let. $\mathrm{Pk}^{+}$. sc.

Foppy. Double pe nny-fiowered old rose color. These grow two feet tall and bear enormous double flowers. Pkt. 10c.

Poppy, Double Mixcd. These are fringed and also peony flowered, all full double in many beautiful color . I was very careful to select only the finest flowers for seed, weeding out all single or inferior ones as soon as the first blooms opened. Colors purple, red, lavender, pink, and pure white. Mix rd pkt̂. 10c.

Poppy, Pr:ckly Annual. Airy single bright yellow flowers borne in great profusion throughout the summer on a very spiny plant two feet high. These have a peculiar beauty but not of a nature that you want to touch. Pkt. 15c.

Portulaca or Rose Moss. Single. all colors mixed. Pkt. 5c.

Portulaca. Double, all colors mixed. Pkt. 10c.

Salpiglosis. Pretty pe'tunia-like flowers in various shades of red, purple and yellow. Pkt. 10c. 
John L. Wilson--Higher Types of Small Fruits and Flowers-Elk City, Kan.

Salvia Azurea. Hardy perennial. three f.et high, bearing spikes of dark blue flowers, blooming first year from seed. Pkt. 10c.

Salvia Farnaceae. Hardy perennial producing a mass of spikes of silvery lavender blooms well above the dense foliage, eighteen inches to two feet high. Blooms first year from seed. Pkt. 10c.

Salvia Splendens, Scarlet Sage. Tender annual growing about two feet high. covered with spikes of bright scarlet flowers. Pkt. 10c.

Sweet Peas, Fine Mixed Spencers. Pkt. 10c; oz. 25c.

Verbenia, Mammoth Flowering. A bushy plant with heads of flowers in many colors, blue, scarlet, yellow. white and striped. Mixed Pkt. 10c.

Scabiosa or Mourning Bride. Lovely colored heads of flowers on long slender stems excellent for cutting. Mixed pkt. $5 \mathrm{c}$.

Zinnia. My zinnias are all full double, of brightest colors, medium size, with long stems, and fine for cutting. Mixed pkt. 10c.

\section{STRA WBERRIES}

My plants are the best this year I ever had and I have the most of them. Plant them early if you can, but I some times plant them till May first. Mulch lightly folowing winter to pro. tect the fruit from dirt, and to keep down weeds.

Senator Dunlap, medium early good size, very prolific. The best berry for home use or local market I know of. Per 100, $\$ 1.00$; per $1000 \$ 7.00$.
Aroma, late, very large, good shipper. Per 100. $\$ 1.20$; per $1000, \$ 9.00$.

Gibson, late, a very prolific grower, large and dark red. Very good for home consumption but not a good shiper. Per 100, $\$ 1.20$; per $1000, \$ 9$.

Drandewine, one of the largest and finest late berries we ever grow here. Per 100, $\$ 1.20$; per 1000 . $\$ 9.00$.

I can also furnish Progressive Everbe: ring, which I personally don't believe ne profitable in this country. l'er $100, \$ 2.00$.

\section{BLACK BERRIES}

littatinny, late, one of the largest ard best berries here. Per doz. 50c; cr $100, \$ 2.50$.

Cariy Harvest, not so large nor so well flavored but earlier than above. $S$ :ne p.ice.

\section{GOOSEBERRIES}

SOTICE! These will be delivered $n$ Kansis only. Customers in other states may order through me but I will have the plants sent from a grower in their own state or on their s d? of the quarantine line.

Oregon Champion, the best large fruited gooseberry. 1 yr. old, each 2); 2 yr. old, each 30c.

Houghton, ine of the best, good sized fruit, not so large as above. 1 yr. each 15c; 2 yr. each 2 idc.

\section{RASPBEIRIES}

Cumberland Black, one of the bast black caps. Per do\%. 50c; per 10\%, s.. 
John L. Wilson-Higher Types of Small Fruits and Flowers-Elk City, Kan.

Kansas Black, a good standard var- plants, each 10c prepaid; per 100, $\$ 3$,

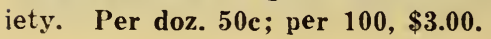
not prepaid.

St. Regis, a good red but rather small fruit. Per doz. 40c; per 100 . $\$ 2.50$.

Moore's Early, black, the best early black grape. Each 20c.

Cuthbert Red, one of the best large red raspberries. Per doz. 50c; per $100, \$ 3.00$.

\section{GRAPES}

Concord, the leading standard black Mine is the genuine, large, redgrape. No. 1, 1 yr. and No. 2, 2 yr. doz. $\$ 1.00$.

\section{Send All Orders To

